\title{
Practical Examination and Reasonable Reconstruction of Realizing the Application Fee of Security Interest Cases
}

\author{
Linqi $\mathrm{Li}^{1, \mathrm{a}}$ \\ ${ }^{1}$ Law School of Henan Normal University, Xin Xiang, China \\ alilinqi726@126.com
}

\begin{abstract}
Keywords: Interest in property; the realization of security interest cases; the application fee
\end{abstract}
\begin{abstract}
In the realization of security interest cases, the application fee is closely related to the interest of the applicant. There is a lack of explicit stipulations about whether the application fee is charged and how to charge it in law and related judicial interpretations, which leads to the confusion of the application fees of the basic people's court at various levels in the judicial practice. Following the principles of ensuring the effective exercise of the applicant's litigation rights, the rules of the market, and basing on the national conditions. The type of fees applied for the realization of the security interest should be the application fee, which charged by the item. On the way of obtaining the remedies for the realization of the security interest cases. The right to file a separate appeal should be given to the parties who realize the case of security interest when they are not satisfied with the decision on the application fee.
\end{abstract}

\section{Introduction}

The problem of the lawsuit cost seems relatively simple, but it is closely related to the interests of the litigants, and related to the fundamental of the judicial system. [1]The realization of the security interest cases is the newly added content of the 2012 Civil Procedure Law. The Civil Procedure Law lacks explicit provisions when the applicant applies to the people's court whether the application fee needs to pay and how in the realization of security interests. However, there is a dispute between the academic and judicial departments whether or not to apply the "Approach to Pay the Cost of Litigation" requirement. This leads to the local grass-roots people's court "fighting each other" in charges, and the confusion of the application fees in the judicial practice. For these chaotic states, this paper takes 2295 cases of realizing security interests all over the country as a sample, and makes an empirical analysis of the status of the application fees charged for the cases of security interests, and puts forward rational construction measures.

\section{Practical Examination of Realizing the Application Fee of Security Interest Cases}

With the implementation of the new Civil Procedure Law, the cases of the security interest accepted by grass-roots people's courts at various places have been on the increase. However, different grass-roots courts have different standards in the collection of application fees for such cases, which can be varied in practice. This chaos not only directly affect the applicant's attitude toward the judiciary in the case of the realization of security interests and evaluation, and also the needs and trust of the general public in the realization of non-compliance of security interests when security interests need to be realized.

The Overall Lack of a Unified Model. There is no unified model in local people's courts at the grass-roots level when the applicant applies to the people's court whether the application fee needs to pay. Some grass-roots people's courts require the applicant to pay the application fees, but some do not. Among the 2295 sample cases collected by 435 grass-roots people's courts from all over the country, 1333 did not charge for the application, accounting for 58.08\%, and 962 of the application fees were collected, accounting for $41.92 \%$.

It is worth noting that the grass-roots people's courts in many provinces (cities and autonomous regions) are not uniform in the practice of collecting fees. 2295 cases were selected from 28 provinces 
(municipalities and autonomous regions) across the country, of which only grass-roots people's courts in seven provinces, including Shanghai, Hainan, Jilin, Heilongjiang, Guizhou, Qinghai and Xinjiang Uygur Autonomous regions, Charge for security interest cases are uniformed and free. The basic people's courts in other 21 provinces (municipalities and autonomous regions) are not in the same position to charge for the realization of security interests. For example, 391 sample cases in Zhejiang Province, 117 pieces of application fees are not charged, and 274 are charged. The ways of the charges are different, including application fees, case acceptance fees, litigation costs and so on.

A Wide Range of Fees Charged. In judicial practice, the realization of security interest cases not only lack the uniform mode in charging, but also existing a wide range of charges in the case of collecting application fees. In the 962 sample cases for collecting application fees, there are mainly three types of charges: the first is the case application fee, which is 488 , accounting for $50.73 \%$ of the total number of charging cases; the second is the case acceptance fee, 435, accounting for $45.22 \%$; the third is the legal fees, 39, accounting for $4.05 \%$. Further subdivision, it can be divided into direct collection of case application fee (admissibility fee, litigation costs), case application fee (admissibility fee, litigation costs) to be charged by half (see Table 1).

TABLE I. The specific circumstances of the name of charges for realizing security interest cases

\begin{tabular}{|l|l|l|l|l|}
\hline Fee name & Frequency & Percentage & $\begin{array}{l}\text { Effective } \\
\text { percentage }\end{array}$ & $\begin{array}{l}\text { Cumulative } \\
\text { percentage }\end{array}$ \\
\hline Case application fee & 449 & 46.67 & 46.67 & 91.89 \\
\hline Case application fees charged by half & 31 & 3.22 & 3.22 & 95.11 \\
\hline $\begin{array}{l}\text { The application fee has not been paid } \\
\text { according to the withdrawal processing }\end{array}$ & 8 & 0.83 & 0.83 & 95.95 \\
\hline Case admissibility fee & 357 & 37.11 & 37.11 & 37.11 \\
\hline Case admissions fee charged by half & 74 & 7.69 & 7.69 & 44.80 \\
\hline The case acceptance fee is fully refunded & 4 & 0.42 & 0.42 & 45.22 \\
\hline Litigation costs & 15 & 1.56 & 1.56 & 97.51 \\
\hline Litigation costs by half & 24 & 2.49 & 2.49 & 100.00 \\
\hline Total & 962 & 100.00 & 100.00 & \\
\hline
\end{tabular}

A Wide Range of Fees Charged. On the standard of charging fees, the grass-roots people's courts practice different ways in different places. It includes the receipt of each piece, according to the amount of the standard charge; by half of the receipt and the amount of the standard charge. In 962 sample cases for collecting application fees, 409 were received per piece (halved), accounting for $42.52 \%$ of the total number of fee collection cases; 553 were charged against the target amount (halved), accounting for $57.48 \%$ of the total number of fee collection cases (see table 2 for details). In the total, the amount charged by the item (halved) is less than the target amount (halved). For each province (municipality or autonomous region), the grass-roots people's courts in all 21 provinces (municipalities and autonomous regions) that charge fees are not unified expect Hebei province. For example, in the case of 104 charges in Jiangsu Province, there are all kinds of fees, which are collected by pieces (38 pieces) and half by pieces ( 1 piece), charged according to the amount of the standard (52 pieces) and half charged by the amount of the standard (13 pieces).

TABLE II. The specific circumstances of the standard of charges for realizing security interest cases

\begin{tabular}{|l|l|l|l|l|}
\hline Charges standard & Frequency & Percentage & $\begin{array}{l}\text { Effective } \\
\text { percentage }\end{array}$ & $\begin{array}{l}\text { Cumulative } \\
\text { percentage }\end{array}$ \\
\hline Charge by item & 379 & 39.40 & 39.40 & 39.40 \\
\hline By half the fee charged & 30 & 3.12 & 3.12 & 42.52 \\
\hline By the amount of the standard charge & 464 & 48.23 & 48.23 & 90.75 \\
\hline By the standard amount by half charge & 89 & 9.25 & 9.25 & 100.00 \\
\hline Total & 962 & 100.00 & 100.00 & \\
\hline
\end{tabular}

There is no uniform standard in the collection of sample cases in which the application fee is charged. According to statistics, in 409 cases which charged by per piece (half) in the realization of security 
interest, the average amount of charge (mean) is 222.13 Yuan, the lowest (minimum) for 25 Yuan, the largest (maximum) for 2000 Yuan, the maximum number is 100 Yuan (plural). The grassroots level people's courts at all levels have reported 40 Yuan, 50 Yuan, 80 Yuan, 200 Yuan, and 500 Yuan (see Table 3) in the amount of the deductions (half) for the realization of security interest. In the sample case of charging the application fee according to the amount of the standard, the amount of the charge is related to the amount of the target, less than 300 Yuan, and the number is up to 466800 Yuan.

TABLE III. According to the item (halved) to collect the application fee to realize the distribution of the amount of the security interest fee cases

\begin{tabular}{|l|l|l|l|l|}
\hline Money & Frequency & Percentage & Effective percentage & Cumulative percentage \\
\hline 25.00 & 5 & 1.22 & 1.22 & 1.22 \\
\hline 40.00 & 24 & 6.10 & 6.10 & 7.32 \\
\hline 50.00 & 44 & 10.98 & 10.98 & 18.29 \\
\hline 80.00 & 39 & 9.76 & 9.76 & 28.05 \\
\hline 100.00 & 209 & 51.22 & 51.22 & 79.27 \\
\hline 200.00 & 5 & 1.22 & 1.22 & 80.49 \\
\hline 300.00 & 5 & 1.22 & 1.22 & 81.71 \\
\hline 400.00 & 10 & 2.44 & 2.44 & 84.15 \\
\hline 450.00 & 10 & 2.44 & 2.44 & 86.59 \\
\hline 500.00 & 14 & 3.66 & 3.66 & 90.24 \\
\hline 1000.00 & 34 & 8.52 & 8.52 & 98.78 \\
\hline 2000.00 & 10 & 1.22 & 1.22 & 100.00 \\
\hline Total & 409 & 100.00 & 100.00 & \\
\hline
\end{tabular}

The chaos of practice standards for the payment of fees not only directly affects the applicant's attitude and evaluation of judicature in the realization of security interest rights cases, but also affects the needs and trust of the general public in the non-litigation process of realizing security interests when security interests need to be realized. It not only seriously damaged the image of the people's courts, especially the image in the eyes of the broad masses of the people, undermining the judicial authority and affecting the promotion of judicial credibility.

\section{Construct the Principle of Applying the Cost Rules for the Realization of Security Interest Cases}

It is necessary to follow certain principles for building the rules of application fee for the realization of security interests. These principles are the basic principles for formulating the rules of application fees for the cases of security interests. The author believes that the principle of application fee for the implementation of security interest cases is not only following the principles of judicial resource consumption is in accordance with litigation costs, benefiting for the dispute to be settled timely and maintenance of public welfare, but also following the principles below:

The Principle of Ensuring the Effective Exercise of the Applicant's Litigation Rights. To enable people to feel fair and just in every judicial case, it is necessary for the state to ensure that the general public can truly and effectively approach the judiciary, rather than just being close to the public in the form of justice. It is also the same in the realization of security interest cases.

In the realization of security interest cases, the applicants are complicated. If the application fee is high or unreasonable, it may invisibly set an obstacle for the applicant to realize the security interest, or affect the applicant through the public relief to realize the security interest. For the applicant, the so-called approaching to justice will become a hopeless luxury, which not only directly affects the full play of non-litigation procedure in realizing security interest, but also indirectly limits the applicant's right endowed by the constitution to obtain relieves with justice. Therefore, the construction of the application fee rules for the realization of security interest cases must be based on the principle of 
ensuring the effective exercise of the applicant's litigant rights, so that the applicants who ask the people's court to auction or sell the property can get effective judicial relief.

The Principle of Following the Rules of the Market. the analysis of cost and income is an inevitable matter for the parties to realize their own rights through judicial means. As some scholars point out, "a rational person usually makes a cost-benefit analysis when choosing a lawsuit or not".[2] In the realization of security interest cases, whether the collection of the application fee is reasonable or not also affects the applicant's choice for realizing the security rights of non-litigation procedure, and the extent of approaching to justice when the applicant enjoys legal security. High application fees and the speed of non-litigation may cause applicants to hesitate outside the courtroom; the application fee and other expenses are almost equal to the amount of the claim, which may make it meaningless to realize the real right of security through the people's court. Only when the application fee is reasonable and affordable, the applicant will choose the public remedy and use judicature to realize his rights. Because based on the pursuit of the maximization of interests, the applicants always tend to choose low-cost remedies when realizing security interests. No matter how well the trial realizes the justice, if the cost is too high, people often have to give up the hope of achieving justice through trial. [3]Therefore, constructing the principle of applying the cost rules for the realization of security interest cases needs follow the rules of the market and set the rules for the application fee of the security interests scientifically in accordance with the basic rules of the market economy, so as to stimulate the applicants to choose non-proceeding when the real right of security needs to be realized, but also make the non-litigation process of realizing real right of security more effective in secured transactions.

The Principle of Basing on National Conditions. Adhering to the principle of basing on the national conditions will helps us more clearly and correctly to understand the problems when collecting application fees in realizing security interest cases. We should put forward perfect measures at the source, completely solve the phenomenon of "arbitrary charging" and promote the effective operation of the non-compliance proceedings in the realization of the security interest case. Adhering to the principle of basing ourselves on the national conditions requires that we take the overall goal of our economic and social development plan and that of promoting the rule of law in an all-round way since the 18th CPC National Congress as guidance. Based on the current comprehensive national strength of our country and the basic situation of social development, taking fully into account the characteristics of the non-compliance of security interests and the carrying capacity or carrying possibility of applicants, it is necessary to construct scientifically and reasonably the realizations of realizing security interests. However, we can't deviate from the general plan and the general goal of "making a second set of one" and formulate some unrealistic rules out of our country's basic national conditions. We advocate using the world's perspective to think about China's problems, boldly absorb and critically learn from the excellent experiences and advanced systems of foreign.

\section{The Construction of Rules of Applying for Cost of Realizing Security Interests}

The type of Charge for the Application in the Realization of Security Interests is the Application Fee. The applicant applies to the people's court to realize the security interest for the purpose of seeking justice, but it takes cost to produce justice by trial. It can be divided into two parts: one part is the public cost, that is, the "trial costs" borne by the state; the other is the private cost, that is, "litigation costs" borne by the litigants. In different countries, based on different national conditions and certain policy considerations, "the cost of producing justice" will be distributed between countries and parties, and reasonable judicial policies will always seek compromise between the two extremes.[4]

In the realization of security interest cases, Article 204, paragraph 1, of Judicial Interpretation of Civil Procedure Law stipulates that the applicants should pay the application fee in the realization of security interests' cases. However, given the eighth provision of Approach to Pay the Cost of 
Litigation, it is contrary. Therefore, on the issue of charging application fees, it is not only inconsistent on the problem of whether or not charged but the provisions on the types of charges are also different between the Judicial Interpretation of Civil Procedure Law and Approach to Pay the Cost of Litigation. The contradictory provisions are the root causes of the arbitrary charging in the realization of the security interest cases in judicial practice. The author believes that the proceedings of realizing security interest cases belong to special procedure, but it deals with only the property right of the parties and should charge a certain application fee. In addition, collecting a certain application fee in realizing the security interest cases may indicate the start of the non-compliance of secured property right, and may be the first access control to prevent "inappropriate indictment."

In the types of charges, the collection of the application fee for security interest should be clear, not the case admissibility fee. The main reason is that there is no civil rights dispute in realizing the security interest cases. According to Article 6 of Approach to Pay the Cost of Litigation, litigation costs include case acceptance fees, application fees and other expenses. The case acceptance fee refers to the fees that the people's court charges the parties according to the relevant provisions of the Approach to Pay the Cost of Litigation after the people's court accepts the litigation initiated by the parties on the dispute over the contents of the civil legal matters. The application fee is the fee paid by the relevant party to the people's court for applying special procedures. As mentioned above, the realization of security interests has non-suitability. The dispute between the claimant and the respondent that there is no substantive rights and obligations may only differ on the way in which the security interests are realized. Therefore, the types of fees applied for the realization of security interests should be the application fee.

Requires the Realization of Security Interests of the Case Application Fee should be collected. In the realization of security interest cases, the standard of the payment of the application fee is one of the most important issues of the application fee rule. The author believes that the application fee for the realization of security interest cases should be collected by each piece. The main reasons are as follows:

First of all, it is required by the characteristics of the trial activities of the people's court. The parties bring contradictions and disputes to the people's court and the people's court settles them mainly through examining the legal relationship of the case. The legal relationship is clear, and the rights and obligations of the parties are also determined. Generally speaking, the complexity of a case is not directly related to the amount of money involved in the case. In essence, the cost of litigation is not the identification of the labor cost paid by the court to examine the legal relationship of a case. The case of the realization of security interests even more so, the applicant submit to the people's court for the realization of security interest, aiming to request the people's court to intervene, and make an adjudication of auctioning or selling the property in accordance with the law to obtain the name of execution, with that applying to the people's court for enforcement. When examining the case of realizing the security interests, the people's court only needs to conduct the examination based on the usual standard of non-litigation cases, eliminating the apparently illegitimate and unreasonable application for realizing the security right. And there is no need to make substantive inquiry into the existence of the right in the substantive law or whether the legal elements are determined, so as to form the inner confirmation. [5]Therefore, the realization of security interests' cases should receive the application fee by per piece, but not in proportion of the target amount.

Second, it is determined by the nature of non-contentious. Realizing the case of real right of security does not substantively deal with the dispute over the civil rights and obligations of the parties, but confirms the legal fact that the claimant applied for the realization of the security right in real estate, which has the power of authority and non-confrontation. [6]The realization of the security right procedure in accordance with the nature and value of the non-litigation system, belonging to the non-litigation procedure. There are distinctive contrast between the litigant and the antagonism of non-litigation and litigation procedures, which reflecting the pursuit of different values. The realization of the procedural independence and the particularity of the application of the security interest right case restrain the punitive ness of the litigation cost system and other functions. Therefore, 
the realization of security interest cases should be charged for each application fee. The saying of not charging the application fees when the target amount is large will result in a substantial loss of court costs, which is a failure to correctly understand the boundary between the trial public and private cost, and does not correctly understand the legislative intent of realizing the non-proceeding of security interest.

Third, it is necessary for the public service of trial activities. Judicial for the people is always the basic purpose of the people's court. To achieve justice for the people, people's courts must firstly make people close to justice. But if the general public can really access to justice, a reasonable system of legal costs becomes very important. The cost of approaching the judiciary is unreasonable or too high, which may lead to people unwilling or afraid to resort the disputes to court. With the continuous development of social economy in our country, the state should enable the general public to share the fruits of economic development, and gradually reduce the proportion of the parties. The realization of security interest is of great significance for giving full play to the role of the security interest system in the market economy and promoting the sustainable development of the whole social economy. Charging the application fee by piece in the realization of security interests' cases reflects the public service nature of the trial activities. It not only helps the applicant to realize the security interest at a low cost, but also enables the judge to conduct the case in a more just atmosphere because of the determination of application fee. And it is more conducive to establishing the authority of law and enhancing the credibility of the judiciary.

Improving the Way of Remedies for realizing security interest cases. The lack of remedial measures is another important reason for the existence of a chaotic phenomenon in the application fees for the realization of security interest cases. In judicial practice, the application fee for the realization of security right cases is generally decided by the judge at the filing. However, the relevant legal and judicial interpretations haven't clearly stipulation in the charge for the application of the case, leaving a great discretionary space for the case judge. According to Article 43 of Approach to Pay the Cost of Litigation, the applicant shouldn't appeal solely on the application fee of the case. If there is any objection to the calculation of the application fee of the case decided by the people's court, they may only request a review from the people's court that made the decision. If the people's court finds that a calculation is really wrong, it shall correct it. Although Approach to Pay the Cost of Litigation stipulates that the applicants have the right to apply for review when there is disagreement on the calculation of the application fee for the case, however, the time limit for the people's court review is not stipulated. Since the applicants can't appeal the case application fee alone, this makes the chief trial judge not pay attention to or even ignore the charge of receiving the case when examining the relevant issues of the case. Furthermore, the absence of charging standards also prevents the presiding judge from examining the appropriateness of application fees. The lack of standards for application fees, the low operability of stipulations in Approach to Pay the Cost of Litigation and the inherent deficiencies in the self-review within the People's Court, all which makes few judicial applicants object to the application fee. As a result, the applicants' remedial approaches are useless. Therefore, the lack of charging standards makes it difficult to collect fees for the application of security interests, and the lack of remedies further aggravates the arbitrariness of application fees.

From the provisions of the countries and regions around the world on remedies of litigation costs, most parties are allowed to file a review request and appeal against the costs of litigation alone. such as France, America, Russia, etc. To improve the remedies for the charging of security interest cases, we should base on the actual situation of judicial operation in our country, draw lessons from extraterritorial practices, and give the right to file an appeal alone if the parties concerned in the security interest claims are not satisfied with the decision on the application fee. That is not only benefit for restricting the discretionary power of litigation costs of the people's court, but also helping to effectively protect the litigant's rights and other legal property rights. If the applicant or the respondent refuses to accept the decision of the people's court on the proportion or amount of the burden of the application fee, the appeal may be filed separately. Depending on the nature of the 
national fee for the application fee, appeals filed solely on the filing fee should be handled by the administrative tribunals of the higher courts to ensure the fairness of the judiciary. Besides, basing on the particularity of filing an appeal solely on the application fee, it is necessary to clarify that such litigation should be exempted from litigation costs and finalized for first instance, so as to improve the efficiency of litigation based on the protection of the applicant's right to appeal.

\section{Conclusion}

The issue of litigation costs related to the root of the judicial system. Through the empirical analysis of the application fee charging situation in the judicial practice, this paper explores the basic principle of rebuilding the reasonable charging standard in the realization of the security interest, and clarifies the concrete measures for charging the application fee in the case of security interest. So as to reasonably and effectively allocate limited judicial resources, effectively guarantee the full realization of the applicants' litigation rights, prevent the applicants from handling irrational and even malicious litigation, and establish the authority and enhance the credibility of the judiciary.

\section{Acknowledgements}

This study was financially supported by the National Social Science Fund of China (Grant No.15BFX162) , one of the achievements of Dr. Start-up project of Henan Normal University (Grant No. qd15104).

\section{References}

[1] [Japan] Taniguchi Anping: "Procedural Justice and Litigation (Supplement)", Wang Yaxin, Liu Rongjun, China University of Political Science and Law Press, pp.55, 2002.

[2] Liao Yongan: "On the nature of civil litigation fees and collection basis", "Politics and Law Forum (China University of Political Science and Law)", 2003 the fifth period.

[3] [Japan] Takase Hidetaku: "Dispute Settlement and Trial System," translated by Wang Yaxin, China University of Political Science and Law Press, pp.267, 2004.

[4] Fang Liufang: "Civil Litigation Fees", "Chinese Social Science", No.3, 1999.

[5] Li Linqi: "Formal Examination or Substantive Examination: An Analysis of the Examination Criteria for Realizing Security Interests Cases", "Politics and Law", No.11, 2014.

[6] Li Linqi: "Procedural Nature of Realizing Security Interests in China", Journal of Hunan University of Science and Technology (Social Science Edition), No.3, 2015. 